\title{
Correction: 2021 DORIS definition of remission in SLE: final recommendations from an international task force
}

van Vollenhoven RF, Bertsias G, Doria A, et al. 2021 DORIS definition of remission in SLE: final recommendations from an international task force. Lupus Sci Med 2021;8:e000538. doi: 10.1136/lupus-2021-000538

The authors want to alert the readers that a typographical error noticed in Box 1, has now been corrected. The final bullet point, referring to medications, was corrected from (prednisolone $<5 \mathrm{mg} /$ day) to (prednisolone $\leq 5 \mathrm{mg} /$ day), as shown below.

\section{Box 1 The 2021 DORIS definition of remission in SLE}

- Clinical SLEDAI=0.

- Physician Global Assessment $<0.5(0-3)$.

- Irrespective of serology.

- The patient may be on antimalarials, low-dose glucocorticoids (prednisolone $\leq 5 \mathrm{mg} /$ day), and/or stable immunosuppressives including biologics.

\section{() \\ OPEN ACCESS}

Open access This is an open access article distributed in accordance with the Creative Commons Attribution Non Commercial (CC BY-NC 4.0) license, which permits others to distribute, remix, adapt, build upon this work non-commercially, and license their derivative works on different terms, provided the original work is properly cited, appropriate credit is given, any changes made indicated, and the use is non-commercial. See: http://creativecommons.org/licenses/by-nc/4.0/.

Lupus Sci Med 2022;9:e000538corr1. doi:10.1136/lupus-2021-000538corr1

D) Check for updates 